Zahrotul Khoiriyah And Moses Glorino Rumambo Pandin

Faculty of Humanities, Airlangga University

Jl. Dharmawangsa Dalam Selatan, Kampus B, Surabaya, 60286

zahrotul.khoiriyah-2020@fib.unair.ac.id; moses.glorino@ fib.unair.ac.id

\title{
Book Review \\ "Filsafat Nusantara; Sebuah Pemikiran Tentang Indonesia" (Philosophy of Nusantara; A Thought About Indonesia)
}

Author: L.A.S. Gunawan Scj; City: Yogyakarta; Publish Year: 2020; Isbn number: 978-97921-6349-0; Number of Pages: 110

In general, the study of Nusantara Philosophy is a form of awareness of the values of the Indonesian people. Nusantara philosophy is the glue of pluralism and diversity as in the formulation of Pancasila and the slogan "Bhinneka Tunggal Ika" means although different, but still one. Therefore, the book "Filsafat Nusantara: Sebuah Pemikiran Tentang Indonesia" was written to present a review of thoughts about Indonesia and Pancasila. As an Indonesian society must certainly have a part in defending the archipelago earth. The author argues that it is important to avoid disintegration due to the variety and complexity of culture and wealth contained naturally in the Indonesian region.

In particular, the study of Nusantara Philosophy should be intended for prospective Church leaders (Church leaders) who are expected to act wisely and carefully in carrying out their entrusted tasks, especially to prepare to face the people and pluralist Indonesian society. Church leaders must have an insight into Indonesian nationality sourced from Nusantara assets. With the study of Nusantara Philosophy, the author believes that Indonesian people can be moved to become a figure who really loves the country $(100 \%)$ and $100 \%$ native members of the Catholic Church (I.J. Kasimo). In addition, the study of Nusantara Philosophy indirectly encourages Indonesians to apply what president Joko Widodo calls "I am Indonesia, I am Pancasila".

This book explained how the perspective of "Filosofi Nusantara" providing a depiction of thought about Indonesia and Pancasila. It is quite interesting because of the clear concept and urgent need for a sense of unity and unity of the nation. Where can this be a new reading source for readers before continuing on western philosophical thinking. According to Frans Magnis Suseno quoted by L.A.S Gunawan, Nusantara Philosophy is part of Cultural Philosophy by using two approaches, namely phenomenological approach that discusses phenomena in every element of Nusantara culture and metaphysical approach that reflects various phenomena in the archipelago. Nusantara philosophy reflects all things related to Nusantara (1).

Overall, this book needs to be reviewed further because it has a different perspective in looking at a country (nation). With the development of the concept of Nusantara insight based on Nusantara philosophy based on Pancasila as the basis of the Indonesian state. Thus, it will bring a new outlook for every citizen and government of the country. Nusantara philosophy is coveted to be able to find the "metaphysical principle" in the framework of the unification of the Archipelago consisting of many islands where this shows the characteristics of the Archipelago, namely as an island nation. Then the principle of metaphysics is a way of thinking as well as assessing the Indonesian government in the context of the Archipelago with all its problems.

By elaborating oncontext of the material, the author provides a formulation of the problem that will guide the discussion of the material. The problem formulation is explained on page three of the book by lifting the four points of problem formulation. First, discuss what is the true nature of Nusantara Philosophy. Second, discuss various phenomena that support the reflection of Nusantara Philosophy. Third, discuss how the relationship between the 
metaphysical study of Nusantara Philosophy based on existing phenomena. Fourth, discuss how the role of Nusantara Philosophy in answering challenges for the challenges of this nation. From the formulation of the problem, it can be said more than enough to meet the information and insights needed by the reader or audience.

This book presents information that the author has not written of the previous philosophy in Indonesia, namely about the typical philosophy of the Archipelago. According to research conducted by IKAPI (Ikatan Penerbit Indonesia) in 2015 (the latest research data is not yet available), there is data that shows that the type of book that ranks first and gets high enthusiasm is the type of children's book. Nusantara philosophy is present because pluralism exists in Indonesia as an island nation and multicultural. In contrast, Indonesian citizens should know or have a way of thinking that is organized systematically as a reflection of the existence and substance of the Archipelago. This can be used as a new and interesting study material.

Directly or indirectly every book read by the reader will leave little or much influence both in terms of insight and knowledge. According to Suhendar in Bollora 2019, enrichment books (non-fiction) are intended to broaden readers' horizons, insights, and experiences (2). So, that can be used as a source of information that can provide benefits for readers in general. In addition, readers will gain insight into the way the Indonesian nation will look and think in the future if Filosofi Nusantara will be developed further and readers can assess whether it has a significant or ordinary influence.

This book has an impact on readers because of the context of the material provided and explained systematically. The context of the material related to the meaning of Nusantara Philosophy, Indonesian culture, language phenomenon, religion, art, Indonesian personality, Indonesian human character, characteristic of Nusantara Philosophy, Pancasila as the orientation of Nusantara Philosophy, justification for Pancasila, the dynamics of Pancasila existence, and philosophy in Pancasila. It shows that what is discussed will be a new view for readers who want a systematic and structured presentation of information.

One interesting study to highlight is related to the phenomenon of language. Language is a collection of several standard words and various forms of pronunciation used as a way (method) to communicate (page 17). In the dictionary of philosophy Lih. Lorens Bagus pages 112-113 explains that there are symbols that can be used in stating or explaining things, including: 1) external material objects; 2) mental matters in (internal); 3) quality; 4) relationships; 5) mathematical logic marks; 6) usability; 7) atmosphere; 8) process; and 9) events. Another interesting study is the justification of Pancasila which is juridically recognized as constitutionally correct in the 1945 Constitution.

From the screening can be said if the evidence provided in this book has been ascertained through checking the correct information. Because each reference uses a reliable and accountable reference among the reference sources used are books by Indonesian writers who are quite influential in Indonesia such as: Koentjoroningrat, Eka Darmaputra, P.J. Soewarno and so on that can be seen in the bibliography section (page 98). Because takes a lot of reviews or reviews of experts' opinions, it influences the author in viewing the study of Nusantara Philosophy as a typical philosophy of the Indonesian nation. But besides, certainly the editors and parties involved in writing the book also from the selected people. The author said that the refinement of the book was assisted by Fr. F.X Nico Pratama, Fr. Laurensius Bobby Lambara and everyone else, so that the objectivity in writing was higher.

In the first and second part of the book pages 1 to 8 books, readers will be introduced to the fundamental question of Nusantara Philosophy which is a typical philosophy were talking about the Indonesian nation (Nusantara). This philosophy has a material object namely Nusantara. The term Nusantara originated from an oath by Gajah Mada related to the unification of various islands in Indonesia where it was still the seeds that make Indonesia as it is today. According to the origin of the word Nusantara consists of two words in Sanskrit: Nusa (island) and Antara (outside). Nusantara was originally used in the mention of islands outside Majapahit located in Java. 
In the page 17 in this book is quite interesting to discuss because it explains the details of language phenomena consisting of the history of Indonesian spelling from several stagesthe first "Spelling van Ophuijsen in 1901" (Malay spelling and Latin letters). The second "Spelling republic of 1947" was inaugurated on March 19, 1947, instead of the previous spelling, also known as Seowandi spelling. Third, "Spelling of the 1975" (designed by a committee led by Prijono and E. Katoppo). The fourth "Spelling Melindo 1959" (the concept of spelling is known in late 1959). The fifth "Perfected Spelling 1972" (in exchange for Melindo's spelling and before EYD was inaugurated there was a spelling elbk). But overall, all are summarized in the language of unity Bahasa Indonesia.

Related to Indonesian man Mochtar Lubis's character, there are 7 dominant characters that describe Indonesian people, including: hypocritical attitude, feudal attitude, irresponsible attitude, superstitious attitude, and weak character. Furthermore, the discussion of authentic characteristics of Nusantara philosophy is based on human philosophy, moral philosophy, and political philosophy. Human philosophy is based on Serat Wedhatama (discussing man's position with God), moral philosophy with a starting point between the universe and the child universe (every life that lives in the universe).

Pancasila as the orientation of Nusantara philosophy is a statement of identity for the Indonesian nation. The talk about Nusantara philosophy should be understood correctly as a philosophical conversation over the existence of Pancasila as a philosophy besides as an idea. Related to philosophy about Pancasila interaction formed is "defining characteristics" as a feature of the Indonesian nation in international relations. From there comes validation (justification) of Pancasila both historically (the complexity of values that develop into a spirit that comes from different ethnic groups in the archipelago), culturally (Pancasila is based on the pluralist dimension of Indonesian society), and philosophically, Pancasila should be seen as a genuine truth (essential).

In a study conducted by Notonegoro on the topic of philosophy in Pancasila, Notonegoro used causal theory in explaining the beginning of Pancasila (page 91). From this theory, it is revealed that there are four reasons for supporting something. First, causa materials (cause in the form of material), second, causa formalis (cause in the form of form), third, causa finalist (cause in the form of purpose), and last or fourth, causa efficiens (cause, that brings consequences). Then, a phenomenological approach (observation based on social symptoms) will be used with the principle of Pancasila principles. In essence, Nusantara philosophy makes the motto of Bhinneka Tunggal Ika the core of the study called Pancasila philosophy.

This book is written in a fairly simple writing style with a sentence structure that is easy to understand by the intended reader. Readers can find out when reading the book. The organization in it is also quite structured because the presentation of materials is done in sequence. Therefore, the reader will more easily absorb the entire contents of the book. For it is medium size, the book that presents as many as 110 pages is interesting when it is read by the public, especially the People of Indonesia and the prospective leaders of the Church who directly become the first attention of the author. The author explained the study of Nusantara Philosophy is implicitly intended to prepare the prospective leaders of the Church to face the diversity of the people as well as the people of Indonesia.

About the discussion of studies, facts or ideas, there has been no description ignored by the author as consideration for readers. This can be seen from the details of the table of contents that in order explain a variety of information and even history (page 24) so that at least the reader can understand what happened before and what can be done to prevent or improve it. For the study, the authors used many reference sources by citing experts' opinions as considerations. So, it is expected that the information presented can be fully understood and understood its origin in every event explored. Therefore, the author tries to describe his point of view with a natural but still weighty style.

The book "Filsafat Nusantara: Sebuah Pemikiran Tentang Indonesia" describes of the typical philosophy of Nusantara (Indonesian nation). The description of the information listed 
takes the opinion of experts in the collection of information sources such as Lorens Bagus, Koentjoronigrat, Nicolas Driyarkara, Mochtar Lubis, Notonegoro and others. It is the result of literature review in the collection of information that is certainly difficult but will produce accurate data quality and facts. The discussion that is poured is also not too heavy to be read by different people except beginners. While the table of contents (material) that is poured in is fairly neat and the material is well sorted.

Overall, the book does not have a panorama of images or statistics of certain research data so readers are required to read in full the description of the writing carefully so as not to tuck into things or words that will later fail to be understood. In addition, the discussion of the contents of complex books will take a long time to understand, especially for people who just want to read about the philosophy of the Archipelago. So, this book is not suitable for children to read, because it will make them think hard and double to be able to understand it as a whole. In terms of material delivery, some are explained in general only, such as the origin of the birth of the term Nusantara (page 2), which is explained that the term Nusantara comes from the oath of a patih during the Majapahit Kingdom, Gajah Mada which is about the unification of the entire island in Indonesia (Nusantara).

A typical study tried to be poured by the author through his book that took the focus of the study on the scope of"Philosophy Nusantara". Therefore, the book is interesting to learn. However, my little suggestion regarding this book is to add some images or statistics of the data so that the reader is not saturated in reading it and can transparently see clear and valid data. Besides, that the author can also write about the continuation of the book. For example, about the effectiveness of Philosophy Nusantara, and recommend whether the book is suitable as additional teaching material in college or not. For readers, it is advisable to read it carefully and thoroughly so that there is no misinterpretation in interpreting each section. However, in writing, the author deserves appreciation from readers for his hard work during the scripting of the book.

Zahrotul Khoiriyah \& Moses Glorino Rumambo Pandin

Airlangga University

\section{REFERENCES:}

1. Gunawan LA. Filsafat Nusantara: Sebuah Pemikiran Tentang Indonesia. Elektronik. de Lima R, editor. Yogyakarta: PT Kanisius; 2020. 6 p.

2. Borolla vrosansen fridolin, Dkk. Keefektifan dan Minat Baca Siswa Pada Penggunaan Buku Pengayaan Non Fiksi di SD. Jurnal Pendidikan. 2019; 4(12): 1715-1722. http://journal.um.ac.id/index.php/jptpp/

\section{AUTHOR:}

L.A.S. Gunawan or known as Rama L.A.S. Gunawan SCJ was born in Brebes on February 3, 1974. He is currently a Lecturer at one of the universities, St. Thomas University, at the Faculty of Philosophy. He also joined as a member of the Imams of the Sacred Heart of Jesus or SCJ. He studied at the Roman-Italian Gregorian University in Licenciat Facoltà in Filosofia. In addition, he also wrote his thesis entitled "True Love according to Dietrich von Hildebrand" 